\title{
Global COVID-19 Pandemic and Indebtedness of Municipalities with Extended Power in the Czech Republic
}

\author{
Eva Lajtkepová ${ }^{1, *}$ \\ ${ }^{1}$ Brno University of Technology, Faculty of Business and Management, Department of Finance, \\ Kolejní 2906/4, 61200 Brno, Czech Republic
}

\begin{abstract}
.
Research background: In theory, indebtedness of municipalities is only ever associated with the acquisition of investments. It is advised that indebtedness should be regulated by the state, but there is a risk of limiting investment in local infrastructure.

Purpose of the article: According to Act No. 23/2017 Coll., municipalities must regulate their own indebtedness and comply with the fiscal rule on pain of penalty. The aim of this text is to provide an analysis and examine the prospects of compliance with the fiscal rule in 205 municipalities with extended power. The analysis is carried out between 2017 and 2019, the risks of compliance in the following years mainly relate to the emerging economic crisis caused by the COVID-19 pandemic. Methods: Given the subject of the analysis, secondary data was used for the research. Data was taken from the Monitor database operated by the Ministry of Finance of the Czech Republic. The obtained data had been processed using standard statistical methods.

Findings \& Value added: To date, the indebtedness of municipalities with extended power is not excessive: the mean and median values are still well below the legal limit. Still, there are some municipalities where the legal limit has been exceeded, or whose indebtedness is nearing the limit. In the event of reduced tax revenue, which is to be expected in the coming years, these municipalities will struggle to comply with the fiscal rule. The consequences will include halting or limiting local investment, and/or reducing the quality of local public goods.
\end{abstract}

Keywords: budget; budget responsibility; fiscal rule; municipality with extended power; public goods

JEL Classification: $H 41 ; H 63 ; H 72$

${ }^{*}$ Corresponding author: lajtkepova@,fbm.vutbr.vcz 


\section{Introduction}

Municipalities in the Czech Republic are considered to be basic territorial selfgoverning units [1] with their basic status, rights, and obligations regulated by Act No. 128/2000 Coll., on Municipalities (Municipal Establishment) [2], and the framework of their management regulated by Act No. 250/2000 Coll., on Budgetary Rules of Territorial Budgets [3]. Municipalities operate based on their own budget and are fully responsible for their activities. The Ministry of Finance does not have the power to intervene directly in their management; however, it always tries to regulate their indebtedness, at least indirectly through monitoring (monitoring indicators).

Only with the adoption of Act No. 23/2017 Coll., on the Rules of Budgetary Responsibility, were strict rules set for the regulation of indebtedness for municipalities and other territorial self-governing units, the non-compliance of which may lead to financial sanctions. Municipalities have adapted to these conditions in the years 2017-2019, and they had no significant problems complying with the legal rules. Nevertheless, in the period of the onset of the economic downturn in connection with the global COVID-19 pandemic, the management of municipalities will become increasingly difficult, as their incomes will decrease significantly.

The above-mentioned Act incorporates the Directive of the Council of the European Union No. 2011/85/EU of 8 November 2011, on Requirements for Budgetary Frameworks of the Member States, and follows other EU regulations (mainly Regulation 1466/1997, Regulation 1467/1997, and Regulation 479/2009) [4, Sect. 1]. It introduces or strengthens the obligations for territorial self-governing units (including municipalities) in order to regulate their possible over-indebtedness.

The new obligation for the municipalities mainly consists of the so-called fiscal rule [4, Sect. [17]. According to this rule, the amount of debt may not exceed $60 \%$ of the average income of municipalities for the previous 4 years; if the municipal debt is higher, the municipality is obliged to reduce the debt by at least $5 \%$ of the difference between the current debt amount and $60 \%$ of the average income over the last four years. If the municipality does not reduce the debt by the mandatory minimum, the state will temporarily suspend the transfer of tax revenues in the amount of this mandatory minimum. In other words, while the municipalities may exceed the debt amount, they are significantly motivated (by the threat of financial sanctions) to repay the debt, not to accumulate it. The budget responsibility indicator is calculated as the share of the municipality's debt and the average of its revenues over the last four years (in \%). Debt is calculated as the sum of short-term and long-term loans, discounted short-term bonds and bills, issued short-term and long-term bonds, promissory notes and long-term promissory notes, repayable shortterm and long-term assistance received, short-term and long-term guarantee liabilities, and other short-term loans [4, Sect. 17, paragraph 5].

The construction of the indicator of budgetary responsibility implies its debatability there is no distinction between the obligations of the municipality. All liabilities are accounted for with the same weight, whether short-term or long-term, whether they are liabilities in the form of bank loans, bills of exchange, or repayable financial assistance from other articles of the budgetary sphere (for example, extra-budgetary funds). The fact is, all of them do not pose the same risk to the budget management of the municipalities, so significant is the specific structure of the municipality's debt. The sanctions that a municipality has to pay in the event of a fiscal rule being exceeded can be doubly unpleasant for its management: even if the state suspends the transfer of shared tax revenue only temporarily, these suspended amounts represent a very harsh budgetary constraint. Tax revenues are a key revenue for all municipal budgets, i.e. even a temporary loss would be considerable for many municipalities - especially for municipalities that are highly 
indebted, i.e. they have to repay both the principal and interest. Therefore, the strict application of legal rules may lead to difficult decisions of local councils on the further development of municipalities in the near future, and it is therefore appropriate to discuss the further sustainability of this rule.

\section{Brief research on the related literature}

Public debt (especially in Europe) has received more attention during times of economic crisis. At first, the interest focused on the problems of the indebtedness of states $[5,6,7,8$, 9], but then the indebtedness of regions and municipalities also attracted attention. It is understandable - the indebtedness of regions and municipalities is part of the public debt of the state and their management affects the everyday lives of every citizen.

The theory of public debt economics (whether of the state, regions, or municipalities) does not strictly reject indebtedness, but indebtedness (usually in the form of a loan or bond issue) is allowed only in times of recession or in connection with the acquisition of investments. Some authors recommend financing public investments with long-term debt (where the debt is repaid at the same time as the investment is used) to ensure intergenerational equity [10]. Intergenerational equity is also linked to debt sustainability [11]. Although [12] point to a certain vagueness and ambiguity of the term "debt sustainability", it can be described as the ability and willingness of the (local) government to repay the debt and not to increase the debt further in the future.

The factors influencing the debt level of regions and municipalities are examined by several authors $[13,14,15,16,17,18,19]$, in the Czech environment [20]. As a rule, they agree that indebtedness can be affected by various factors - especially demographic (population, in some countries migration and immigration), economic (unemployment, economic level of the region, income of the region's population), and political (composition of local government, political-economic cycle). However, no source has yet mentioned the impact of the epidemic (and the subsequent sharp economic downturn).

Authors [21, 22, 23] frequently emphasize the importance of the public regulation of indebtedness by higher government, but at the same time they point out that while the applied fiscal rules lead to the control of local indebtedness, they can lead to limited investments in local infrastructure and to time delays. A counterweight of higher control and regulation can be the internal control of municipalities themselves [24].

The impact of the budgetary responsibility rules adopted in Europe as a reflection of the financial crisis on lower levels of government is examined by [22] and [18]. They agree that these rules can have a positive effect on reducing the level of debt of municipalities or regions; however, these lower levels of government always have less room for loans and indebtedness than the state.

\section{Objective of the text, methods, research file, and data used}

The main goal of the paper is the analysis and perspective of the sustainability of the fiscal rule in 205 municipalities with extended power in the Czech Republic. The analysis of compliance with the fiscal rule is performed in the years 2017-2019, i.e. from the effective date of Act 23/2017 Coll. with regard to the size of municipalities. Sustainability risks in the following years are mainly related to the situation of the oncoming economic crisis caused by the global COVID-19 pandemic.

Municipalities in the Czech Republic are divided into three categories according to the scope of the delegated powers (i.e. according to the scope of state administration services 
the performance of which was entrusted to the municipal authorities by law). All municipalities perform at least the basic scope of state administration activities in the delegated powers. Municipalities with the so-called authorized municipal office (388 of these municipalities) perform state administration in specified territorial districts beyond the scope of the delegated powers of municipalities with an "ordinary" municipal office; municipalities with extended power (there are 205 of these municipalities in the Czech Republic; informally labelled as "small districts") perform state administration in the specified territorial districts even beyond the scope of the delegated powers of municipalities with authorized municipal authorities.

Table 1. Number of municipalities with extended power in individual regions.

\begin{tabular}{|c|c|c|}
\hline Region & $\begin{array}{c}\text { Number of municipalities } \\
\text { with extended power }\end{array}$ & $\begin{array}{c}\text { Number of municipalities in the region } \\
\text { in total }\end{array}$ \\
\hline Středočeský & 26 & 1144 \\
\hline Jihočeský & 17 & 623 \\
\hline Plzeňský & 15 & 501 \\
\hline Karlovarský & 7 & 133 \\
\hline Ústecký & 16 & 354 \\
\hline Liberecký & 10 & 215 \\
\hline Královéhradecký & 15 & 448 \\
\hline Pardubický & 15 & 451 \\
\hline Vysočina & 15 & 704 \\
\hline Jihomoravský & 21 & 672 \\
\hline Zlínský & 13 & 307 \\
\hline Olomoucký & 13 & 401 \\
\hline Moravskoslezský & 22 & 300 \\
\hline Total & $\mathbf{2 0 5}$ & $\mathbf{6 2 5 3}$ \\
\hline
\end{tabular}

Source: [25]

Prague was excluded from the examined sample. Its size is incomparable with other municipalities, and in addition, it has a special status - it is both a city and a region. Therefore, its inclusion in the sample would necessarily skew the results.

Due to the researched issue, it was possible to use only secondary data sources: all data was taken from the monitor of the Ministry of Finance of the Czech Republic [25]. The obtained data was processed by standard statistical methods: first by the methods of descriptive statistics, then by correlation and regression analysis.

\section{Results and Discussion}

\subsection{Results of descriptive statistics}

Let us look at an introduction to the basic results of descriptive statistics on budgetary responsibility indicators in the 205 municipalities with extended power (Table 2). 
Table 2. Results of descriptive statistics.

\begin{tabular}{|c|c|c|c|}
\hline Indicator & $\mathbf{2 0 1 7}$ & $\mathbf{2 0 1 8}$ & $\mathbf{2 0 1 9}$ \\
\hline MIN & 0.00 & 0.00 & 0.00 \\
\hline MAX & 93.77 & 80.13 & 73.01 \\
\hline Average & 13.98185 & 14.00668 & 14.67488 \\
\hline Median & 10.57 & 11.47 & 11.88 \\
\hline Modus & 0.00 & 0.00 & 0.00 \\
\hline Mode frequency & 39 & 40 & 44 \\
\hline Lower quartile & 2.32 & 1.47 & 1.33 \\
\hline Upper quartile & 20.98 & 22.29 & 20.12 \\
\hline Dispersion & 229.2357 & 209.9175 & 248.9754 \\
\hline Standard deviation & 15.14053 & 14.48853 & 15.77895 \\
\hline Coefficient of variation & 108.2870 & 103.4401 & 107.5236 \\
\hline
\end{tabular}

Source: own work based on [25]

From the results, it can be read that municipalities with extended power differed significantly in the value of the budget responsibility indicator: on the one hand, there are municipalities where this value is zero (in other words: they were not indebted at all), on the other hand, there are municipalities that exceed the fiscal rule (let us remind the reader that it is set at $60 \%$ ). It is very gratifying that zero indebtedness is reached by the most municipalities (mode): out of the total number of 205, it was a total of 39 municipalities in 2017, then 40 municipalities in 2018, and even 44 municipalities the following year, while 32 municipalities achieve zero indebtedness in all three monitored years.

The highest indebtedness (MAX) was reached in the individual years by three municipalities/cities: in 2017 by Liberec, in 2018 by Olomouc, and the following year by Židlochovice. The values of the median and the upper quartile are also very good in terms of adherence to budgetary discipline: they indicate that, for the most part, municipalities with extended power carefully monitor their debt levels. However, the values of the coefficient of variation indicate that the set is quite inconsistent in terms of the value of the budget responsibility indicator, while the values of the standard deviation indicate the same - the absolute variability of municipalities with extended power in terms of the value of calculated budget responsibility is quite high. Let us now look at the development of the budget responsibility indicator for the four municipalities that showed the highest value for this indicator (Table 3).

Table 3. Development of the indicator of budgetary responsibility in selected municipalities in the years 2017-2019 (\%).

\begin{tabular}{|c|c|c|c|}
\hline Municipality & $\mathbf{2 0 1 7}$ & $\mathbf{2 0 1 8}$ & $\mathbf{2 0 1 9}$ \\
\hline Liberec & 93.77 & 77.59 & 65.79 \\
\hline Olomouc & 86.68 & 80.13 & 70.69 \\
\hline Kravaře & 61.40 & 49.05 & 38.67 \\
\hline Vrchlabí & 61.38 & 55.26 & 52.64 \\
\hline
\end{tabular}

Note: Exceeding the fiscal rule is highlighted

Source: own work based on [25]

Based on the above data, it is evident that in all municipalities with extended power where the value of the budget responsibility indicator exceeded $60 \%$ in 2017 , there was a decrease, albeit of varying importance, in the value of the budget responsibility indicator. This is especially evident in Liberec, where there was a decrease from an extremely high $93.77 \%$ to $65.79 \%$ in 2019 .

Based on the above results, we can therefore assume that the adoption of Act No. 23/2017 Coll. and the setting of the fiscal rule helped to effectively motivate municipalities to reduce their indebtedness - even in 2017, highly indebted municipalities (Liberec, 
Olomouc) significantly reduced their indebtedness and tried to approach the $60 \%$ limit set by the budgetary responsibility indicator.

\subsection{Results of correlation and regression analysis}

To determine the strength of dependence between the variables "value of the budget responsibility indicator (municipal debt)" and "number of inhabitants in the municipality", correlation coefficients were calculated with the following result:

Table 4. Correlation coefficients (2017-2019).

\begin{tabular}{|c|c|c|c|}
\hline & $\mathbf{2 0 1 7}$ & $\mathbf{2 0 1 8}$ & $\mathbf{2 0 1 9}$ \\
\hline Correlation coefficient & 0.31888 & 0.23956 & 0.14302 \\
\hline
\end{tabular}

Note: the correlation is significant at $\mathrm{p}<0.05$

Source: own work based on [25]

Based on the calculated values of the correlation coefficients (2017-2019), we can state a rather weaker dependence between the value of the indicator of budgetary responsibility and the size of the municipality. Although the lower value of the correlation coefficients is a certain surprise, even in the conditions of the Czech Republic for municipalities with extended power, we can confirm those views that consider the size of the city one of the possible factors for their indebtedness $[15,20]$. However, it is quite clear that there are several factors influencing municipal indebtedness [20].

In regression analysis, we generally describe the relationship between a dependent variable and an independent variable. Because the aim of our analysis is compliance with the fiscal rule with respect to the size of municipalities, the variable value is the budget responsibility indicator $(y)$, while the independent variable is the size of the municipality measured as the number of inhabitants in the municipality $($ Prom $2=x)$. The regression results are shown in Table 5.

Table 5. Results of regression.

\begin{tabular}{|c|c|c|c|c|}
\hline $\mathrm{N}=205$ & $\mathbf{b}$ & $\begin{array}{c}\text { Standard error } \\
\text { from b }\end{array}$ & $\mathbf{t}$ (203) & p-value \\
\hline Absolute member & 11.77926 & 1.171071 & 10.05854 & 0.000000 \\
\hline Prom2 $=\mathrm{x}$ & 0.00010 & 0.000030 & 3.51559 & 0.000541 \\
\hline
\end{tabular}

Source: own work based on [25], data from 2018 was used for the calculation

Based on the above results, we can see that the model is statistically significant (at the $5 \%$ level of significance). We can interpolate the data with a regression line, which can be described in the following way:

$$
\begin{gathered}
y=a x+b \\
y=0.00010 x+11.77926
\end{gathered}
$$

The positive sign of the coefficient $a$ means that with the increasing size of the municipality, the mean value of indebtedness (values of the indicator of budgetary responsibility) increases. Based on the value of the coefficient $a$, we estimate that with each additional inhabitant of the municipality with extended power in the Czech Republic, the mean value of the budgetary responsibility indicator increases by $0.00010 \%$. At first glance, this change may seem very small, but it must be emphasized that even an increase in the population by one is small in reality - especially in larger cities, which the municipalities with extended power usually are. 
The coefficient of determination was also calculated: $\mathrm{R} 2=0.57389$. This means that $57.389 \%$ of the variability in the value of the budgetary responsibility indicator can be explained by the chosen regression model. The unexplained part of the variability of the value of budgetary responsibility can be caused by other factors: individual sources state e.g. fiscal autonomy, demand for local public goods [20], political fragmentation of local government $[15,20]$, unemployment, immigration rate [18], political cycle at the local level [15], and others.

\subsection{Impact of the COVID-19 pandemic on the sustainability of the fiscal rule}

The revenues of municipalities in the Czech Republic are highly dependent on transfers from the state budget, especially on the transfer of the share of shared taxes (VAT, both income taxes), the national revenue of which is redistributed (the state, regions and municipalities). The fiscal power of municipalities is not very high; they can only decide on real estate tax and local fees.

However, the collection of shared taxes is highly dependent on the economic cycle, i.e. if the economy is in a deep recession (for 2020, the Ministry of Finance of the Czech Republic expects an economic decline in GDP of 6.6\% year-on-year [25]), the national collection of these taxes is drastically reduced (see Table 6). For municipalities, this means a dramatic reduction in their income, which they cannot compensate from other sources (see Table 7 - the data is for all municipalities in the Czech Republic). In other words, it would be much more difficult for municipalities to comply with the fiscal rule - the denominator of the budgetary responsibility indicator would decrease rapidly and with the same debt, the risk of exceeding its required value would increase. In this case, one could speak of a debt trap at the local level.

Table 6. Tax revenues of the state budget (January - June, bill. of CZK).

\begin{tabular}{|c|c|c|c|}
\hline Tax & $\mathbf{2 0 1 8}$ & $\mathbf{2 0 1 9}$ & $\mathbf{2 0 2 0}$ \\
\hline VAT & 209.24 & 113.23 & 105.38 \\
\hline Personal income tax & 48.41 & 56.19 & 46.85 \\
\hline Corporate tax & 29.21 & 31.07 & 27.61 \\
\hline
\end{tabular}

Source: [25]

Table 7. Revenues and expenditures of municipal budgets - comparison of 2019 and 2020 (always for the first half of the year, bill. of CZK).

\begin{tabular}{|c|c|c|}
\hline & $\mathbf{2 0 1 9}$ & $\mathbf{2 0 2 0}$ \\
\hline Revenues & 175.4 & 166.3 \\
\hline Expenditures & 149.0 & 157.9 \\
\hline
\end{tabular}

Source: [25]

If the economic downturn caused by the global Covid-19 pandemic were long and extremely deep, municipal revenues would fall dramatically. Municipalities would have to respond to this situation with an equally drastic reduction in expenditures: this would mean reducing (or at least temporarily suspending) investment projects and reducing the quantity and quality of local public services (e.g. public transport, municipal services, education, health, etc.). In the case of municipalities with extended power, this restriction of public goods would be even more painful for the inhabitants and would have a greater impact; these municipalities provide state administration activities and services not only for their own inhabitants, but also for the inhabitants of the entire administrative district. In other words, limiting the quality and quantity of state administration activities and services would ultimately affect all residents of the Czech Republic. 
Certainly, if the revenues of municipalities are significantly reduced, it is possible to expect that many of them will not comply with the fiscal rule in the following years (especially those municipalities that were already just below the set limit in 2019), even if they did not go into debt any further. If municipalities cannot influence a large part of their income and, on the other hand, have higher expenditures, it is not in the power of a good manager to maintain a balanced economy. It is therefore entirely appropriate to discuss how to strengthen municipalities' own revenues and reduce their dependence on tax transfers from the state budget, as well as to discuss the softening of the fiscal rule (let us mention that the state softened its obligation to the fiscal rule in spring 2020 and the same can be requested by municipalities). Or at least municipalities should not be exposed to the sanction involving the temporary suspension of tax revenue from the state budget, because this sanction would further worsen their situation (with all the consequences, e.g. stopping investments, restrictions on public goods, etc.).

\section{Conclusion}

At the beginning of our brief summary, it should be noted that until spring 2020, the indebtedness of municipalities (including municipalities with extended power) and compliance with the fiscal rule were not perceived as a significant economic or social problem. According to the Ministry of Finance, about $8 \%$ of municipalities did not comply with the fiscal rule (winter 2018/2019), but municipalities usually worked on a gradual reduction of their indebtedness [25].

Our results show that municipalities with extended power differed in the value of the budget responsibility indicator: on the one hand, there are municipalities that were not indebted at all (32 municipalities even in none of the monitored years), on the other hand, there are municipalities that have exceeded the fiscal rule. The most indebted cities in all three years were Liberec and Olomouc. However, the median and upper quartile for the whole set were still below $60 \%$, i.e. the discipline of compliance with the fiscal rule was very good in 2017-2019.

In order to determine what effect the size of the municipality has on the value of the budget responsibility indicator, we performed a correlation and regression analysis. The calculated correlation coefficients showed a rather weak dependence between these variables; however, the calculated values were statistically significant. This conforms with the conclusions of other studies $[15,20]$. The regression model was also statistically significant, and the regression line equation was calculated. Using the coefficient of determination, we used a regression model to explain $57.389 \%$ of the variability in the value of the budget responsibility indicator. The unexplained part of the variability of the value of budgetary responsibility is caused by other factors: individual sources state e.g. fiscal autonomy, demand for local public goods [20], political fragmentation of local councils $[15,20]$, unemployment, immigration rate [18], political cycle at the local level [15], and others.

Because the revenues of municipalities in the Czech Republic are highly dependent on the transfer of shared taxes from the state budget, since the spring of 2020, when the COVID-19 pandemic broke out and there was a shock decline in the economy, municipal revenues have been declining significantly. Municipalities must respond to this fact - they are already starting to suspend investment projects, while another reaction will be to reduce the quantity and quality of local public goods (e.g. public transport, municipal services, etc.). Because municipalities with extended power perform state administration activities not only for themselves, but also for the surrounding municipalities from their administrative district, this situation will affect all citizens of the Czech Republic. Despite saving measures, we can expect that in the coming years many municipalities will not be 
able to comply with the fiscal rule (especially those that were already just below this limit in 2019). It may be appropriate to propose a discussion on whether municipalities must comply with the fiscal rule in such a difficult economic period (let us emphasize that the state softened its obligation of the fiscal rule in the spring of 2020, so municipalities can request the same). Or at least municipalities that do not comply with this rule should not be subject to a sanction involving the temporary suspension of tax revenue from the state budget, because this sanction would further worsen their situation (with all the consequences of stopping investments, restricting public goods, etc.).

\section{References}

1. Constitution of the Czech Republic of 16 December 1992, as amended, Article 99.

2. Act No. 128/2000 Coll., On municipalities (Municipal Establishment), of 12 April 2000.

3. Act No. 250/2000 Coll., On budgetary rules of territorial budgets, of 7 July 2000.

4. Act No. 23/2017 Coll., On the rules of budgetary responsibility, of 17 January 2017.

5. Abel, A. B. (2018). Optimal debt and profitability in the trade-off theory. Journal of Finance, 73(1), 95-143.

6. Armingeon, K., Cranmer, S. (2018). Position-taking in the Euro crisis. Journal of European Public Policy, 25(4), 546-566.

7. Baldi, G., Staehr, K. (2016). The European debt crisis and fiscal reactions in Europe 2000-2014. International Economics and Economic Policy, 13(2), 297-317.

8. Sinn, H. W. (2018). The ECB's fiscal policy. International Tax and Public Finance, 25(6), 1404-1433.

9. Tamborini, R. (2014). Interest-rate spread and public debt dynamics in two-country monetary union portfolio model. Open Economies Review, 25(2), 243-261.

10. Holtz-Eakin, D. (1991). Bond market conditions and state-local capital spending. National Tax Journal, 44(4), 105-120.

11. Stavins, R. N., Wagner, A. F., Wagner, G. (2003). Interpreting sustainability in economic terms: dynamic efficiency plus intergenerational equity. Economics Letters. 79(3), 339-343.

12. Botoc, C., Pirtea, M., Nicolescu, C. (2011). Public debt sustainability analysis: EU case. Annals of the University of Oradea: Economic Science, 1(1), 409-415.

13. Kiewiet, D. R., Szakaty, K. (1996). Constitutional limitations on borrowing: an analysis of state bonded indebtedness. Journal of Law, Economics and Organization, 12(1), 62-97.

14. Aronson, T., Granlund, D. (2017). Federal subsidization of state expenditure to reduce political budget cycles. International Tax and Public Finance, 24(3), 536-545.

15. Guillamon, M. D., Bastida, F., Benito, B. (2013). The electoral budget cycle on municipal policy expenditure. European Journal of Law and Economics, 36(3), $447-$ 469.

16. Veiga, L. G., Veiga, F. J. (2007). Political business cycles at the municipal level. Public Choice, 131(1-2), 45-64.

17. Fisher, R. C., Wassmer, R. W. (2014). The issuance of state and local debt during the united states great recession. National Tax Journal, 67(1), 113-150.

18. Vera, J. O. (2018). Explanatory factors and limitations of Spanish local debt. Academia Revista Latinoamericana de Administración, 31(2), 360-377. 
19. Balaguer-Col, M. T., Prior, D., Tortosa-Ausina, E. (2016). On the determinants of local government debt: does one size fit all? International Public Management Journal, 19(4), 513-542.

20. Hajek, P., Hajkova, V. (2009). Debt analysis of Czech municipalities. Scientific papers of the University of Pardubice. Series D, 14, 36-42.

21. Egorov, G., Harstad, B. (2017). Private politics and public regulation. Review of Economic Studies, 84(4), 1652-1682.

22. Bröthaler, J., Getzner, M., Haber, G. (2015). Sustainability of local government debt: a case study of Austrian municipalities. Empirica, 42(3), 521-546.

23. Rodden, J. (2002). The dilemma of fiscal federalism: Grants and fiscal performance around the world. American Journal of Political Science, 46(3), 670-687.

24. Gras, E., Hernandez, J., Palacios, M. (2014). An explanation of local debt in spain based on internal control system. Lex Localis, 12(4), 775-792.

25. Ministry of Finance of the Czech Republic (www.mfcr.cz). 